\title{
Legal Argumentation - Is it a Science or Art?
}

\author{
By Mihály MacZonkai*
}

\begin{abstract}
The uncertainties in methodology of interpretation and argumentation and the lack of specific methods to be followed bring the interpreter into a particular situation in law. However, it cannot be ruled out that the art of legal reasoning may possibly exist. Accordingly, in the interpretation of the law and in legal hermeneutics the main issue is the judicial conduct. The sociological situation of the judge does not allow her to follow the criteria prevailing in science. This does not mean the disparagement of judicial activity, because the justification of the verdict may have a strong intellectual force, even if it does not meet the academic requirements. An approach that holds that the proper interpretation and argumentation should be a scientific one is too narrow, as there is another rationality, that is, the adjudicating intellect. This by its very nature not only deals with the exploration of general principles and rules, although these also play a role in this form of reasoning, but also attempts to find justifiable solutions for each particular case.
\end{abstract}

Keywords: legal reasoning, interpretation methods, civil and common law approach, prudential wisdom, judicial skills

\section{POSITIVIST THEORETICAL APPROACHES TO INTERPRETATION METHODS}

The opportunity to assess the quality of judgments is based on the assumption that we have a clear set of criteria to qualify them, or as a weaker demand at least we have a protocol which is designed to ensure a proper procedure for concluding a correct judgement. Theoretically, such a set of criteria or protocol, according to the nature of judicial process, in the fields of fact finding, interpretation of rules and legal reasoning could be established. This paper concentrates on the latter two fields. The effort to measure the quality of judgements suggests that it is possible to work in this area with scientific precision or at least with bureaucratic accuracy. With respect to the starting point of the analysis it seems to be necessary to overview the traditions and the actual state of things from a Hungarian perspective.

In Hungarian jurisprudence the dominant doctrine of interpretation is of German origin, and therefore it is worthwhile reviewing these fundamentals. One major effect for the problem-solving doctrine has its roots in a concept held by nineteenth-century German jurisprudence, which makes a distinction between the rules, propositions and the legal institutions of the law. Legal institutions, according to this approach, are concluded from rules of substantive law, but it is only one side of the matter, since rules can be deducted from previously established abstract institutions. That solution of German jurisprudence has been widely accepted, since with that approach the methods of science were taken over. That solution is reasonable as it respects the practical needs of law; meanwhile, the legal doctrine receives a central role in interpretation, because the jurisprudence has to insert the

*Associate Professor, Department of Civil Procedural Law and Legal Sociology, Faculty of Law, University of Pécs. E-mail: maczonkai.mihaly@ajk.pte.hu 
rules of substantive law into the system of legal concepts. ${ }^{1}$ Therefore the dominance of dogmatic jurisprudence is established, because the meaning of positive law at the end has been defined by the legal doctrines.

Yet in German jurisprudence, which has made an invaluable contribution to the development of legal dogmatics even beyond Germany, the questions in the field of interpretation of law are discussed rather summarily. It is not surprising, because that approach was a science of rules and less a science of the application of law. However, the effect of that approach continues up until the present day as positivist theories of legal interpretation still basically stand on the same foundation which has been elaborated previously. ${ }^{2}$ The change is exhausted in a broader catalog of interpretation methods. This conclusion can be drawn from representative comparative research that instead of the classic four methods enlists twelve, ${ }^{3}$ but a closer look at them shows that these can be also interpreted as a more differentiated approach to the classical interpretation methods.

Concerning the establishment of the fundamental doctrines on legal interpretation, as with regard to many other issues, an exponent of German jurisprudence, Savigny, should be highlighted. Savigny sees in interpretation an intellectual activity which involves the interpreter attempting to understand the way of thinking of the legislature. Formally, the change in his approach is such that earlier teachings of the dual grammatical and logical interpretation approach originating from Donellus are discarded and replaced by a single legal interpretation consisting of four elements, namely grammatical, historical, logical and systematic. $^{4}$

Savigny developed the doctrine on the four classical interpretation methods, but did not specify the relationship between them. He had no theory on when and how those methods should be used, therefore it has been left to the discretion of a law enforcing agent. ${ }^{5}$ Therefore, in that area, in the use of the means of interpretation, deciding on their line, and on the weight of them, the discretionary power of the interpreter of the law remains remarkable. However, a remarkable and little-known element of Savigny's theory is that he distinguishes normal interpretation from interpretation occurring in pathological cases. Pathological interpretation of the law occurs if law is deficient or doubtful, with the latter possibly being caused by an indefinite (incomplete, ambiguous) or incorrect (the legislator said either more or less than intended) expression. To resolve these situations three instruments are available: the internal structure of legislation, the relationship between the wording and the basic idea of the law and the intrinsic value eventually concluded by the interpretation. ${ }^{6}$ Apart from this Savigny also pays special attention to the interpretation of the legal system as a whole, which is a theory to handle the gaps and inconsistencies in the legal system. ${ }^{7}$ Here analogy plays an important role, which is based on the idea of gapless law, for in analogy we argue from conclusion to premise that the two cases deserve the same treatment. However, Savigny does not accept that the similar evaluation criteria may be justified by legal policy, but on the contrary, the basis of analogy is the theoretical

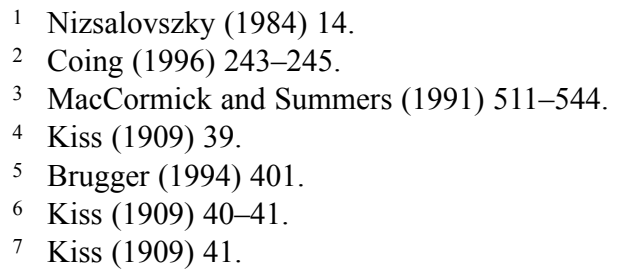


conceptual abstraction of legal provisions. ${ }^{8}$ It could be the subject of a separate analysis why - in addition to the normal methods of interpretation - the concept of pathological methods of interpretation has not received more attention in legal theory. However, methods in pathological cases do not constitute a fundamentally different legal technique to those used in the normal interpretation of the law. In both cases, the institution and the concepts of law prevail over the legal rule. In normal interpretation an argumentation using systematic and logical devices, and in pathological cases the relationship between the text of the law and the basic idea and the analysis of the legal system as a whole are able to create this dominance.

Savigny's and the German Begriffsjurisprudenz's theory so far is a new approach compared to previous legal literature, which held that the purpose of interpretation is not necessarily to clarify legislative will. The jurisprudence of concepts for the challenging of problems of legal interpretation of law summed up the rules of the law in a pyramid system where at the bottom of the pyramid the most concrete rules are located, while the more comprehensive rules and concepts, from which specific rules can be deduced, are at the top. Thereby the law creates a perfect gapless system. This approach can be easily connected to the theory of legal positivism. Since the missing rules of law can be deduced from general rules and conceptions, the application and interpretation of law is basically a logical activity according to that logical deductive system. ${ }^{9}$

A different approach to the problems of application and interpretation of law is linked to Hart. According to Hart, a distinction must be made between the clear and the so-called hard cases. If the content of the law is clear, the application of law is a simple matter of using linguistic analysis, subsumption and syllogism. ${ }^{10}$ Therefore in clear cases, where the applicable rule can be mechanically connected to the facts, syllogism dominates. Using the syllogism means that there is no serious debate about which rule applies and that the meaning of a rule is clear. Therefore definition of clear cases is essentially based on the fact that in the decision the syllogistic method has been used. ${ }^{11}$

When problems arise during the application of the law due to a lack of clear and unambiguous content, we refer to this situation as being a hard case. The reason for that is that the language is always inaccurate, and therefore, although the rule in many cases has a clear content, in some cases the content is not clear and therefore judicial creativity is required..$^{12}$ So a hard case is that which the syllogistic method cannot determine, the rule itself or the meaning of the applicable rule not being entirely clear. ${ }^{13}$ It is evident that Hart basically represents a positivist approach to law as it has a determined normative content and the problem for the interpretation is to explore that meaning. What is different from the traditional positivist theory is the effort to integrate non-positivist approaches with differentiating tasks in clear and hard cases. This argument is plausible, as a rule, and can have clear meaning in relation to particular facts and can be doubtful in relation to other sets of facts. Hart fully recognises that the general problem with the syllogistic reason is

8 Kiss (1909) 42.

9 Nizsalovszky (1984) 12.

10 Hart (1993) 125-126.

11 Lyons (1992) 147.

12 Hart (1993) 125-126.

13 Lyons (1992) 147. 
that the conclusion is true when it follows from the premises, but to be a true conclusion the premises should be true at the same time. ${ }^{14}$

Hart sees the law as a set of rules in the same way as other positivist thinkers, but notices another feature of legal rule. He maintains that every rule has a core meaning when there is without doubt the kind of situation covered by the rule. On the other hand, every rule has an indefinite character due to its vagueness and open texture when the application of the rule to some situation raises doubts, which he defines as the penumbra of doubts. ${ }^{15}$ His famous example of the core meaning and the penumbra of doubts concerning the same rule provides a good example for a better understanding. Our rule that 'no vehicle may be taken to the park' covers for example motor-cars without any doubt, therefore this is a core meaning of the rule. But this rule has a penumbra if we have to decide whether under the rule a bicycle, roller skates, or an electrically propelled car are allowed to enter the park. ${ }^{16}$

According to Hart the core meaning allows subsumption and syllogism, but the penumbra requires another approach. ${ }^{17}$ In penumbra cases it is uncertain ab initio in which cases the rule applies, therefore in difficult cases (every penumbra is a hard case) there is no one correct answer. The solution therefore may be reached by finding a compromise between different interests, or as a second method Hart suggests a search for what is reasonable, which may be anticipated by social actors and shall be supervised by court decisions. ${ }^{18}$

As we have seen in his theory Hart wants to combine the syllogistic, formal interpretation in cases of core meaning while maintaining the opportunity for an openended legal reasoning for penumbra cases for the application of the same rule. With this solution Hart tries to join the anti-positivist legal reasoning theories to the positivist interpretation theory, but while integrating the two methods his theory raises the question of primacy of legal reasoning methods. His theory suggests that the precedence is the formal, syllogistic method and the secondary method is the anti-positivist reasoning method:

The open texture of law means that there are, indeed, areas of conduct where much must be left to be developed by courts or officials striking a balance, in the light of circumstances between competing interests which vary in weight from case to case. None the less, the life of law consists to a very large extent in the guidance both of officials and private individuals by determinate rules which, unlike the applications of variable standards, do not require from them a fresh judgement from case to case. ${ }^{19}$

This implied hierarchy is not without doubt, or to paraphrase Hart it is a penumbra. Hart's example to explain his theory is disarmingly simple, no serious or complicated values being at stake and further it can be argued that most rules of law are not so simple. ${ }^{20}$

The problem with hard cases is that they are decided by means of law, or whether the judge's decision in the case actually goes beyond the law. ${ }^{21}$ Clear statements of propositions allow for the application of law by logic and syllogism. The open texture of rules excludes

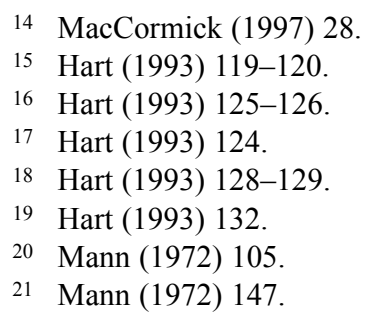


this and requires a different approach. ${ }^{22}$ Therefore Hart's theory is a rather pragmatic approach in order to synthesize the various doctrines and concepts of jurisprudence and the wide variety of views.

The positivist approach in an implicit way accepts that legal theory has the same foundation as other social sciences. However, in the field of legal theory reservations can be raised against patterns of social sciences. The basic conditions of jurisprudence differ from sciences as it deals not only with empirical facts. In jurisprudence the theoretical problem frequently is that the scope of the rule is fundamentally different from a description of a phenomenon, such as in the case of the validity rule..$^{23}$ The explanations of jurisprudence are especially contrary to those used in natural scientific theories because they are not causal in nature. Explanations in legal theory in relation to their objects develop hypotheses, which standardize the material and have some explanatory power. ${ }^{24}$

After these considerations one may reach the conclusion that the interpretation of the law is a research method which concentrates on judicial conduct. ${ }^{25}$ The social situation of the judge does not allow for the application of the criteria that prevail in the sciences to judicial decisions. Judges do not work under conditions that would enable them to present justifications of an academic nature. The authoritative interpretations developed by higher courts deal with a wide range of cases, so it is impossible to expect such a degree of specialization, which is natural in a university or research institute environment. Moreover, the primary audience of reasoning is not the academic scientific community. The judge's legal interpretation must respect certain traditions, the opinion of peers and should respect political realities. This does not mean the disparagement of judicial activity, and there might be a strong intellectual force in reasons for a judgment, even if it does not meet the scientific canon. The clear presentation of a case, highlighting the principle at stake, and taking into account the expectations of parties require significant creativity. ${ }^{26}$

\section{HEURISTIC APPROACH TO INTERPRETATION IN LAW}

Certainty of law and predictability of judicial decisions are goals which can never be achieved entirely, but it is hard to argue that those are not important aims and values in law. Still the question arises whether it is possible in law to find methods of interpretation which could provide a strict protocol in adjudication. Examination of the problem is certainly justified, despite the reservations formulated in relation to these ideals' exact legal or ideological role. Reservations suggest that the one right answer thesis is a naive response searching for the lost predictability of law, while the search for specific legal logic and reasoning method is nothing more than nostalgia for the lost autonomy law. ${ }^{27}$ Perhaps full certainty of law and predictability of judicial decisions cannot be guaranteed, yet a more realistic description of judicial decisions can reduce the uncertainty.

The theoretical foundation of an alternative approach is not based on the methods of sciences, as scientific rationality is not the only rationality, because if it were the only one we would narrow areas of human intellect. The foundation of non-scientific rationality goes

22 Hart (1993) 124.

23 Villa (1992) 83-84.

24 Villa (1992) 80-81.

25 Kevelson (1988) 126.

26 Posner (1998) 275.

27 Posner (1992) 318. 
back to Aristotle, who differentiated between the two types of the human intellect. One is the scientific understanding, which is linked to the constant non-variable elements of the world. The other form of reason is the prudential, judging intellect, which is connected to the changing elements of the world. The latter by its nature not only deals with the general principles and causal laws of exploration, although it assumes that knowledge. The special task of the judging intellect is the understanding of the particular. While scientific reason provides explanations of the world, judging intellect awards opinions. However, these are not arbitrary and unfounded opinions. In shaping opinions the same scientific techniques, induction, deduction and causal explanations are used. The difference stems from the variations of the principles of explanation and understanding. Scientific explanations require certain premises and axioms, while opinions have more uncertain premises, and general or mainstream beliefs provide the starting point for argumentation. ${ }^{28}$ In the absence of philosophical arguments and fundamentals Jerome Frank has reached similar conclusions. According to him each of the parties to the lawsuit could rely on principles which were in their favor in the case in question. In every case at least two confronting principles have to be resolved in the absence of clear guidelines on how to do it properly. ${ }^{29}$

The use of logic in legal arguments cannot rule out the use of other, non-logical arguments to support the decision. The latter is obviously not able to secure the correctness of a conclusion in the strict sense of the word, yet it can create a sufficient basis for acceptance. Despite the fact that the truth (validity) premises are not proved, it does not mean that our conclusions are incorrect..$^{30}$ Furthermore, collision of different considerations does not mean necessarily that different solutions are of the same weight, because it is possible to find the best answer even among other dissenting reasonable opinions. ${ }^{31}$ If there is no difference between the good and the wrong decision then the argument is essentially based on subjective factors and the content of the decision is merely a question of power. ${ }^{32}$ Finding the right answer, therefore, means that, despite the arguments presented by the two sides, we are able to decide which line of argument is stronger, and which is a better reasoning. ${ }^{33}$ The most important characteristic of a good opinion is therefore the ability to persuade. The persuasive power sometimes depends on little differences. One option would be better, if it considers more carefully the circumstances and arguments which are contrary to the final conclusion. It may express doubts regarding the conclusions and thus get more credibility. ${ }^{34}$

The decision based on prudential wisdom is not an irrational decision. This is indicated by comparing the two decision models. As is explained in decision theory, two decision models can face each other, the algorithmic and the heuristic. The difference between the two is that the latter, in contrast to the former, does not necessarily guarantee only one kind of solution. ${ }^{35}$ Science may be based on the algorithmic decision model, but adjudicating is closer to the heuristic model. In the heuristic method, especially in problem solving, the main issue is to find the right way of solving the problem, while we know that the final

28 Pattaro (1992) 65-68.

29 Frank (1963) 71.

30 Lyons (1992) 148.

31 Lyons (1992) 149.

32 Scharffs (2004) 737.

33 Posner (1992) 347.

34 Posner (1998) 737.

35 Samuel (1994) 90-122. 
solution which is reached is not the only final solution, but also that the direction is not the only possible one.$^{36}$ After these, justification of a judgment is nothing else than achieving a balance between the decisions, rules and principles. ${ }^{37}$

However, for a fair and reasonable decision more factors could be taken into account than law, for example, the values of the community, although the value-based approach raises some problems. The decision will not be arbitrary if the values, which have influenced the judgment, are not the personal values of the judge. Fulfilling that requirement, the judge just completes the unfinished work of the legislature. To achieve that goal one needs a coherent theory that describes the operation in the legislature of those values and their relationship to each other. There is no such theory for political processes, since politics is not science. ${ }^{38}$

The heuristic model, based on prudential wisdom, has an excellent example in the dissenting opinion of Oliver Wendell Holmes in the case of Lochner v. New York. ${ }^{39}$ According to the facts of the case the legislation of the State of New York limited the working hours in bakeries up to sixty hours in a week and ten hours in a day. Lochner, a bakery owner, had violated the law, and had to pay a fine of fifty dollars. In the lawsuit, before the Federal Supreme Court Lochner cited the XIV Amendment of the Constitution, which prohibits depriving any person of property without due process. The majority opinion overturned the district court's decision on the grounds that the meaning of the amendment is that the state shall not interfere with freedom of contract.

Holmes in his dissent as a first step gives examples on restrictions of freedom of contract, such as the prohibition to work on Sundays and contract of usury. Following these old examples a more recent one was mentioned, the lottery game, which cannot be organized by anyone. After a list of examples he draws the conclusion that the law in principle restricts and limits the freedom of contract. So the real question is to what extent the law might limit the freedom of contract. According to Holmes, by declaring the unconstitutionality of that law, behind the majority opinion essentially Herbert Spencer's views can be found, which form a sociological theory of individual freedom, which sees a danger in the intervention of the state. Holmes questions on his part whether the amendment enacts Spencer's social statics. In his reasoning conclusion: "But a constitution is not intended to embody a particular economic theory, whether of paternalism and the organic relationship of the citizen to the state, or of the laissez faire." Finally, he makes a comment on the nature of the applied rule "General propositions do not decide concrete cases. The decision will depend on a judgment or intuition more subtle than any articulate major premise."

A Hungarian case also gives a good example of the general rule not saying too much about the scope of its application. ${ }^{40}$ The Hungarian civil code recognizes the prohibition of the abuse of rights. During that period (in the 1960s) in order to overcome the housing shortage Hungarian law allowed for local councils to rent out privately owned property without the consent of the owner at a price fixed by law. Thus law also defined the legitimate housing needs of the owner and family to ensure the opportunity to rent out the so-called surplus boundaries. The local council selected in a four-bedroom house two separate rooms for two tenants, so the widow owner with her two daughters shared the other two rooms. In

36 Gordley (1995) 561.

37 Baum Levenbook (1992) 209.

38 Lyons (1992) 153.

198 U.S. 45 (1905).

P törv. III. 20 059/1963. 
order to improve the living conditions for the family the owner added two new rooms to the house, so again the three-member family lived in four rooms, with which they had reached the upper limit of legitimate housing needs as defined by law. After that, one of the tenants left the property.

The owner in her application firstly claimed the right of disposal of the empty room and if that was not possible, alternatively, requested that his daughter be appointed as a tenant of the room, because in the meantime she had grown up to an age which allowed her to be a claimant to such a tenancy. The mother argued that the law on housing prefers and gives first place to relatives. Her primary request was denied by all of the forums. Her secondary request was also denied by administrative authorities and by the first instance court. The appellate court reversed the lower court's judgment and appointed the majorityaged daughter as tenant. After a so-called legality protest the Supreme Court reversed the appellate court's decision.

According to the Supreme Court, the law in this case does not require the appointment of a relative as tenant, if their housing needs are satisfied. The owner lived with her two daughters in four rooms, which was consistent with legal requirements set out in the legislation. In the case of the appointment of the majority-aged daughter the rest of the family, mother and younger daughter would share four rooms with which they would have exceeded their housing needs. This situation is contrary to the purpose of the legislation and would violate the rules of the civil code, as it constitutes an abuse of right. The reasoning states that in pursuing their interests the subjects have to behave in such a manner that in exercising civil rights their conduct should be in harmony with the interests of society.

Case law has developed a doctrine of abuse of rights in French law. First, a French court considered the construction of a new chimney illegal, because the previous one also operated properly. The reconstruction essentially did not provide an improvement for the builder, yet the new chimney actually blocked the adequate ventilation of the chimney of the neighboring house. In its reasoning the court states that the builder had no serious and legitimate interest in what he did. The same approach was followed by another court where a spa owner increased the yield of water. Consequently, the neighbor's production of water decreased by more than 60 percent. However, the person increasing the production did not commercialize that growth, but simply wasted it. Since the purpose of the increase was to cause harm, the court ruled that liability for damage was justified. Finally, in 1917 the Court of Cassation also dealt with the matter, confirming various earlier appellate courts' practices. During the Great War, on one of two adjacent lands a company operated airplane hangars. To ensure safe operation they made a purchase offer to the neighbor, but because of the high price the purchase was not completed. After that, high pales were placed on the adjacent land. On one occasion, an airplane crashed on pales while landing. The court found the tortfeasor's liability on the grounds that the intent had been to cause damage. ${ }^{41}$

Does Hungarian and French law deal with abuse of rights in the same way or are there differences in the application of the rule? Probably French courts would have arrived to a different solution in the Hungarian case and that is not only due to the moral judgment of the case and to different views of law and society, but differences in legal doctrine can have their impact. In French cases there has always been a specified person, the ,neighbor', who suffers harm as a consequence of exercising a right. In the Hungarian case, there is no specific person who has suffered. In the case of French law it can be argued with reason that

41 Gutteridge (1993) 32-39. 
the abuse of a right requires the harm of a specific person, while in Hungarian law that requirement does not exist. As Holmes put it, general propositions do not decide cases.

\section{INTERFERENCE OF NORMS AND FACTS - HOW TO BUILD UP A CASE}

These examples of the application of law and on the working of the heuristic model of interpretation raise a question concerning interpretation, which is the confusing nature of the relationship between law and facts. A formal approach based on logic makes a clear distinction between the world of historical facts and legal norms. This approach is based on Kant's philosophy, which distinguishes between the Sein and Sollen worlds. In this context, Sollen is the world of rules and the facts of the world belong to Sein. Thus, the choice of the applicable rule is completely independent of the relevant facts. It is the process of the application of law that creates connection between the closed world of norms and the historical facts. According to that the lawyer discovers the facts and interprets law, but the two are not directly connected. In the nineteenth century this European approach was based on the successful French codifications and on German jurisprudence, which is itself the science of rules. ${ }^{42}$ However, departing from the Kantian concept the whole problem can be seen in a new light. That approach states that facts influence the meaning of rules and rules also constitute facts. ${ }^{43}$ That theory is very reminiscent in common law and is far away from the traditional perception of law in civil law systems.

If someone sees in the application of law something else than a logical application of the rules to the facts set out in advance, that person has a special expectation of lawyering. In the application of law intuition can be a great aid, which is a capability to see all the details and weigh the various factors. ${ }^{44}$ Such intuition is developed by legal socialization. The lawyer has an idea of how to approach the case and what kind of arguments are acceptable. The holder of such a capability possesses good judgment. Therefore intuition requires a kind of tacit knowledge..$^{45}$ Intuition helps to solve problems but that solution has to be accepted by others as well. For this purpose the ability to build up a case, to choose from the historical facts the legally relevant ones, and the ability to tell a story plays a very important role. The reconstruction of facts has a fundamental importance in the common law, as its logic differs from civil law thinking.

The continental approach obviously is more easily inclined to consider law as a system of organized rules, as from the Middle Ages legal studies were based on codes at universities. In contrast, the English legal approach can be well illustrated by the assessment of the work of Blackstone's Commentaries. The Commentaries were an attempt to summarize the rules of English common law in a new comprehensive form. Despite all the respect it had received, it was not successful from an academic point of view, because common law education, despite the Commentaries reputation, could not be institutionalized at that time. Blackstone's work did not satisfy any of the requirements of practitioners either ${ }^{46}$ According to Starkie, a barrister of the Inner Temple, it is easy to study law from the Commentaries, but at the same time it is a great danger to the lawyer's mind as it diverts attention from the real task of a lawyer. The principles and rules of general application hide

42 Merryman (1978) 223.

43 Van Dunné (1996) 456.

44 Sunstein (1996) 139.

45 Posner (1992) 342.

46 Lobban (1991) 41-46. 
the practical application and scope of those rules and principles. ${ }^{47}$ For an English legal practitioner the internal relationship between rules is of secondary importance, the real primary knowledge in law is the knowledge of the functioning of those rules.

As a consequence of the problems raised by the Commentaries, another attempt appeared to summarize common law on a different foundation. John Reeves, in his work The History of English Law, attacked the whole methodology of Blackstone and challenged the view that Blackstone examined English law through modern legal concepts. Reeves considers that approach fundamentally wrong, as the old law could be interpreted according to its historical context. The law for Reeves is not a closed scientific system, but a forum that responds to the needs of society. ${ }^{48}$ For Blackstone, law is a clear and concise material, while according to Reeves, law is born randomly when a problem occurs, and the judge does not draw conclusions from pre-existing rules, but concludes from the circumstances to the rules. ${ }^{49}$

Interpretation of a rule tailored to the circumstances of the case, and consideration of the potential consequences is not only the specialty of common law. In fact, in the application of law the civil law system also uses storytelling methods by highlighting particular circumstances. An excellent example of this method is the Hungarian 'explosive television set' case.$^{50}$ According to the facts, the television set in the home of the applicant exploded during an operation and as a consequence of the explosion furniture and curtains caught fire. Previously, the TV set had been repaired and it was proven that during repairs a part of the set was replaced by a part which was not suitable according to factory-set criteria. It was well known that with this type of TV set such accidents occur relatively frequently. The defendant, the manufacturing factory, based their defense in part on the fact of the non-professional replacement of the fuse. On the other hand, the factory relied on the fact that the television set in question met the quality criteria required by Hungarian law and industry standards and that the state authority in jurisdiction investigated the product and approved its commercialization on the market. It is clear that the factory put forward defense of second line in order to neutralize the fame of producing a defective product.

The court ruled that the manufacturer has a liability for its defective products pursuant to article 339 of the Civil Code. According to that a defendant may escape liability by proving that it had acted in that given situation as expected. The court found that the defendant had failed to comply with the requirement set out in civil law. It is not enough to prove that the product complied with every legal regulation and industrial standards and had an authorization from a quality control authority. The product has to meet certain social expectations too. If the product does not meet the social expectations the existence of official commercial authorization is irrelevant. In this case it is a legitimate social expectation that a TV set even after an improper replacement of fuse would not explode causing great potential danger to property and a serious risk of personal injury. By introducing the concept of legitimate social expectations into the circumstances of the case the Hungarian Supreme Court disclosed a set of facts from the historical facts and the defense remained without any means to win the case.

47 Lobban (1991) 49.

48 Lobban (1991) 51.

49 Lobban (1991) 53.

50 Legfelsőbb Bíróság (Supreme Court) Gf: III. 31.208/1984 
To build up a story, the structuring of the factual elements can appear in judicial reasoning. ${ }^{51}$ A Hungarian magazine has denied an application for rectification of an article with the title 'The Hardest Mission II' and subtitle 'The Fake Trial of P fighter pilots from 1951 to 1990'. In that article there was a charge that V F urged T T's interrogators to beat the victim. The applicant stated that it was a false statement. The judgment of the first instance court ordered the newspaper to publish a rectification. The first instance court in its argument reasoned that the object of the lawsuit is not that the State Security Authority engaged in an illegal and cruel procedure, which is now common knowledge, and that should not be generally examined, but that one of the organization's leaders, the applicant, actually participated in the interrogation of $\mathrm{T} T$, and actually urged the interrogators to beat him. The magazine moved to prove the alleged facts by the testimony of the author of the disputed article, T T. The first instance court held that the witness had an interest in the outcome of dispute, and was explicitly biased against the applicant. In the assessment of the testimony the court could not ignore the fact that $\mathrm{T} \mathrm{T}$ seemed to recognize the applicant after forty years of those events. As there was only one piece of direct evidence, which was disputable for several reasons and was not supported at least by some indirect evidence which specifically related to the case, the first-instance court did not ascertain that the alleged facts of the magazine's article state the facts as they had happened. At the same time the court did not ascertain either that $\mathrm{T} T \mathrm{~T}$ had published misstatements. According to the court it was a common knowledge that a leader of the State Security Authority could make an order in any case even without having formal jurisdiction therefore it could not be ruled out that the applicant contributed to the investigation against $\mathrm{T} T$. Consequently, the first instance court ordered the defendant to publish the rectification because the challenged facts were not proven by defendant.

The Supreme Court as second instance court agreed with the statement of the first instance court in its reasoning that the object of the lawsuit is not to investigate the violations of law committed by the State Security Authority in general, but it had to be to examined whether the applicant as the organization's Intelligence Main Department head was present at T T's interrogation and made such a statement as 'beat him comrades, if he does not confess everything in details'. These allegations of the magazine's article are disputed in the lawsuit.

After that the Supreme Court built up its own story. The magazine's author in the criticized article wrote on his personal history and described the persecution of the members of the air regiment $\mathrm{P}$, and in the meantime made a personal reference to the applicant. In his witness testimony before the court, $\mathrm{T} \mathrm{T}$ submitted the facts in the same manner as was written in that article. He evoked within a non-confuted factual context how the interrogator intimated that the applicant had been the person present at the interrogation and that the interrogator had warned him that it was vain to hope that the recognition of service merit received from the applicant's father before his arrest could have improved his situation. T T testified also beside these events that it was fully apparent to him - as it was stated by his interrogator - that the applicant was present at his interrogation when he had seen the applicant's photos of that period in a book written by the applicant. With the aid of photos he could identify the applicant himself. $\mathrm{T} T$ has already been pointed out in the first instance trial that he had talked to his fellow-prisoner about the circumstances of his interrogation,

51 BH 1992108 Legf. Bír. IV 20 726/1991. 
and he had learned from them the name of M F's son. That part of T T's testimony was confirmed by a witness at the trial before the second instance court.

The court concluded on this basis that the court of first instance erred in its assessment of the evidence. It made an error when it balanced the credibility of the applicant and T T and made a non-rational conclusion from the evidence. The applicant's book containing autobiographical elements enumerates a lot of serious, morally reprehensible acts committed by the applicant, while $\mathrm{T} T$ was a victim of a power structure which secured the background for committing such acts. Therefore it is an incorrect conclusion that the testimony of T T in the absence of other evidence cannot be used as evidence because $\mathrm{T} T$ was involved in the outcome of the dispute and is biased against the applicant.

As stated by the court itself the fact that in the civil law trial the questioned witness claims the applicant took part in inflicting injuries which he had suffered forty years earlier, and therefore was angry with the applicant, does not render inadmissible the statement that the witness recognized the applicant with the aid of contemporary photographs and so therefore the witness knows - as one of the interrogators also stated - that the applicant was present at his interrogation. This conclusion is supported even more, because the applicant's autobiography contains many references, and a presentation of allegations which reasonably and appropriately support T T's testimony. From the arguments above, and from the common-sense knowledge on the functioning of the State Security Authority it was not impossible that the applicant was present at the interrogation. The applicant's request was denied.

The difference between the two courts is the approach to the problem. The first instance court adopted a mechanical, algorithmic conclusion. In this case the magazine had to prove the correctness of its statements. The statements of facts by the biased witness and applicant contradicted each other; thereby there is no clear evidence on the facts. Therefore the case should be adjudicated in favor of the applicant. It is an acceptable argument in law. The second instance adopted another solution with a sound reasoning. Which judgment was of better quality?

This case is clear evidence of the importance of legal skills in solving hard cases. These skills cannot be replaced by algorithm or an exact theory of interpretation. ${ }^{52}$ In these circumstances the method is necessarily imprecise, and the definition and vagueness of law and legal institutions may be treated as an advantage. The lack of precision, an indefinite framework, enables the institution to adapt to the changing conditions of the times. ${ }^{53}$ This technique requires empathy and pays less attention to the adequate knowledge of the text, the main aim being to understand the situation, with the role of logic being of secondary importance.$^{54}$ The art of persuasion consists of three elements: rationality, emotion and personal integrity. Rhetoric, which is used in persuasion, tries to impress emotions and uses a logical deductive reasoning model as well, but there is a fundamental difference between the rhetorical and logical deduction. In the case of logical deduction conclusion necessarily follows from the premise, while in rhetorical argument we are only dealing with probabilities. $^{55}$

It should be emphasised that the distinction and competition between the logical interpretation of norms and let's say prudential explanations are much older. It is as old as

52 Posner (1998) 211.

53 Sunstein (1996) 43.

54 Posner (1992) 339.

55 Scharffs (2004) 752-756. 
the European legal tradition. There have been several efforts to build up a moral based deductive law especially in the natural law schools of the 17th and 18th centuries and these efforts had a great effect on contemporary law, but the law has never lost its prudential character and the prudential way of analysing tried to defend its position and place emphasis on the close-to-life way of thinking in opposition to the artificial thinking of the syllogistic method. The difference may be illustrated by the following comment of Albericus de Rosate referring to Richardus Malumbra:

[Richardus] made fun of certain Doctors who were his contemporaries who tried to treat our science in syllogistic, sophistic and dialectical manner. ... [This manner] had its origin with the ultramontane Doctors of whom some, in many things, the majority, were more subtle than useful though some were of great excellence and knowledge. In our science, when it is the question of chopping someone's head off, to argue about formed and form, substance and accident, and in similar ways and by syllogistic arguments is not, I believe, well founded. Nor was this style followed by our older fathers and Doctors: Iohannes [Bassianus] who was sufficiently subtle, Azo, Bulgarus, Martinus, Odofredus or others. They argued from the witness of our laws which were close to the matter in question. I do not say that one cannot argue from the lesser to the greater or from the contrary meaning and in other ways we find approved in our law and which we urge upon all whoever applies himself to our law. But they followed in the footsteps of our older jurists and fathers and doctors, sticking to the text and the gloss and the opinions of the most respected doctors. They did not turn to fables or make arguments so logistic and sophistic that they have no truth but only its appearance. Nor is this only a vice of our modern Doctors and advocates. This disease, indeed, has crept into the science of theology for the modern preachers forsake sacred scripture for figures, philosophers, poets, and fables. ${ }^{56}$

One of the modern trends of interpretation, Perelman's 'new rhetoric', goes back to the Roman law tradition, emphasizing the dialectical approach as opposed to the method of the glossators, by whom the axiomatic interpretation of the law had been elaborated. It seems that the Romans used the interpretive method that we previously called heuristic reasoning based on prudential reason. They were great masters of telling stories, Ulpian's opinion ${ }^{57}$ illustrating the Roman method. The case concerns a will, which was wrongfully obliterated by a deliberate or negligent act of persons other than the testator. Ulpian quotes an opinion which denies the availability of an action because it is impossible to estimate the damage. But according to Ulpian, it is a viewpoint from the testator's position, however, from the position of the heir the situation looks to be a different one as the will is equivalent to a signed document acknowledging debt. Thus Ulpian's solution originates in a different approach to the case. This opinion illustrates well the famous Roman notion that law shall not be induced from rules, but rules are to be induced from law. ${ }^{58}$

The legacy of Roman legal literature can be divided into two parts, the 'institutiones', which were legal textbooks, and 'responsa' (opinions) of jurisprudents. The latter is concerned with solving legal cases and helped in the interpretation and application of the

56 Cited by Gordley (1995) 35 .

57 D.9.2.41.

58 D.50.17.1. 
law, thus aiding the practice of law. Textbooks were given the task of showing the state of the law in the quickest and most convenient way, thereby facilitating the teaching of the law. Textbooks converted law into propositional statements, which were grouped around a specified institution, but these rules were not fact-specific rules, but law-related statements, the central subjects of the curricula of the rule itself. The study of the rule was based on its nature and on the connection with other rules. A further step in the development of abstraction was the creation of definitions and institutions which later could be used in legislation. ${ }^{59}$ The Roman legal literature from a quite large perspective successfully dealt with the old controversy by separating textbooks for the purpose of acquiring the knowledge on rules from the literature, which was designed for practical problem-solving.

\section{CONCLUSION}

After these considerations now it is possible to answer the question of the conference as to how to measure the quality of judgments. In my opinion that question is based on an assumption as to what the role of the judge is, and what the nature of the relation between the judge and the law is. There can be many answers to this. Is it like that of a mathematician starting from axioms and postulates deducing the solution of the problem? Or is it more like the artist who creates, according to the standards of engineering, the design of the building? Or is it similar to the referee, who directs play according to the rules, as the situations arise? Or is it like a chef who cooks from recipes, but adds her or his taste as well? Is a judge a co-author with legislation in adjudicating? Is that role similar to the roles of a bureaucrat, legislator, or the wise men of the community $?^{60}$

My answer to these questions is that the judge's role is not that of a mathematician, nor of a bureaucrat, neither of a referee. After that it is a matter of taste, whether one compares that role to the role of an artist or of a chef. It can be similar to an artist or to a chef, because in legal reasoning the judge is bound by rules and traditions. But perhaps the best approach is that in fact a judge is the co-author of a common opus. In legal reasoning we must use prudential wisdom with heuristic methods. There is no real opportunity to measure the quality of judgments, as we cannot create a precise professional protocol for legal argumentation.

\section{LITERATURE}

Brugger, W., 'Legal Interpretation, Schools of Jurisprudence, and Anthropology: Some Remarks from a German Point of View' (1994) 42 The American Journal of Comparative Law 396-417.

Coing, H., A jogfilozófia alapjai [Fundamentals of Legal Theory] (Osiris 1996).

Dunné, J. M. van, 'Narrative Coherence and Its Function in Judicial Decision Making and Legislation' (1996) 44 The American Journal of Comparative Law 435-461.

Frank, J., The Law and the Modern Mind (first published 1930, Anchor Books 1963).

Gordley, J., 'Comparative Legal Research: Its Function in the Development of Law' (1995) 43 The Journal of American Comparative Law 21-43.

Grodin, J. R., In Pursuit of Justice - Reflections of a State Supreme Court Justice (University of California Press 1989).

Gutteridge, H. C., 'Abuse of Rights' (1933) 22 Cambridge Law Journal 22-45.

Hart, H. L. H., The Concept of Law (first published 1961, Clarendon Press 1993).

Kevelson, R., The Law as a System of Signs (Plenum Press 1988).

59 Samuel (1994) 60-61.

60 Grodin (1989) 133-134. 
Kiss G., A jogalkalmazás módszeréröl [On the Method of Application of Law] (Athenaeum 1909).

Levenbook, B. B., 'The Role of Coherence in Legal Reasoning' in AA Aarnio and ND MacCormick (eds), Legal Reasoning, vol 2 (Dartmouth 1992) 199-218.

Lobban, M., The Common Law and English Jurisprudence 1760-1850 (Clarendon Press 1991).

Lyons, D., 'Justification and Judicial Responsibility' in AA Aarnio and ND MacCormick (eds), Legal Reasoning, vol 1 (Dartmouth 1992) 145-166.

MacCormick, N. D., Legal Reasoning and Legal Theory (Clarendon Press 1997).

MacCormick N. D. and Summers, R. S. (eds), Interpreting Statutes - A Comparative Study (Dartmouth 1991).

Mann, C. J., The Function of Judicial Reasoning in European Economic Integration (Martinus Nijhoff 1972).

Merryman, J. H., 'On the Convergence (and Divergence) of the Civil Law and the Common Law' in M Cappelletti (ed), New Perspectives for a Common Law of Europe (Sijthoff - Bruylant 1978) 197-233.

Nizsalovszky, E., 'Fogalomkutató és érdekkutató jogtudomány, a szabad jogi iskola és a tiszta jogtan' [Conceptoriented and Interestoriented Legal Theory, Free Law Movement and Pure Theory of Law] in E. Nizsalovszky (ed), Tanulmányok a jogról [Studies on Law] (Akadémiai Kiadó 1984) 4-23.

Pattaro, E., 'Models of Reason, Types of Principles and Reasoning, Historical Comments and Theoretical Outlines' in AA Aarnio and ND MacCormick (eds), Legal Reasoning, vol 1 (Dartmouth 1992) 65-78.

Posner, R. A., Law and Literature (Harvard University Press 1998).

Posner, R. A., 'The Jurisprudence of Scepticism' in AA Aarnio and ND MacCormick (eds), Legal Reasoning, vol 1 (Dartmouth 1992) 315-379.

Samuel, G., The Foundation of Legal Reasoning (Maklu-Nomos-Bruylant-Blackstone 1994).

Scharffs, B. G., 'The Character of Legal Reasoning' (2004) 61 Washington and Lee Law Review 733-786.

Sunstein, C., Legal Reasoning and Political Conflict (Oxford University Press 1996).

Villa, V., 'Legal Science between Natural and Human Sciences" in AA Aarnio and ND MacCormick (eds), Legal Reasoning, vol 1 (Dartmouth 1992). 